Sally Mastwyk ORCID iD: 0000-0002-9503-1007

Helena Frawley ORCID iD: 0000-0002-7126-6979

\title{
The impact of pelvic organ prolapse and/or continence surgery on pelvic floor muscle function in women: a systematic review
}

\author{
Ms. Sally Mastwyk ${ }^{1}$ - School of Allied Health, La Trobe University, Melbourne, VIC \\ Dr Jodie McClelland ${ }^{1}$ - School of Allied Health, La Trobe University, Melbourne, \\ VIC
}

Dr Anna Rosamilia ${ }^{2,3}$ - Monash University, Department of Obstetrics and Gynaecology, Clayton, VIC; Monash Health, Clayton, VIC

Associate Professor Helena Frawley,5 - Department of Physiotherapy, Faculty of Medicine, Nursing and Health Sciences, Monash University, Melbourne, VIC; Centre for Allied Health Research and Education, Cabrini Health, Melbourne, VIC

Institution: La Trobe University, VIC

Correspondence: Sally Mastwyk, Physiotherapy La Trobe University, Bundoora VIC 3086. s.mastwyk@latrobe.edu.au+61 394796364

Short title: Impact of pelvic surgery on female pelvic floor muscles.

Removed from main document for double blind policy:

- First sentence following heading 2 Materials and Methods: This systematic review was registered in the PROSPERO database (CRD42015027193) and was reported in accordance with PRISMA guidelines. ${ }^{23}$

This is the author manuscript accepted for publication and undergone full peer review but has not been through the copyediting, typesetting, pagination and proofreading process, which may lead to differences between this version and the Version of Record. Please cite this article as doi: 10.1002/nau.24025. 
- ACKNOWLEDGEMENT: We thank Mr Satish Warrier for assistance with information about specific surgical procedures.

\begin{abstract}
1) Aims: To systematically review the evidence for the effect of pelvic organ prolapse (POP) and/or continence surgery on pelvic floor muscle (PFM) morphometry and function in women, and to investigate whether a relationship exists between PFM measures and clinician-reported objective pelvic floor outcomes post-operatively.
\end{abstract}

2) Methods: Six electronic databases were searched until March 2018. Studies were included if they examined the effect of POP and/or continence surgery on the PFM in women, and reported pre and post-operative data. Methodological quality was assessed using a modified Downs and Black checklist. Three meta-analyses were planned based on post-operative follow-up time.

3) Results: Twenty-one studies met the inclusion criteria. Varied surgical interventions and 33 different PFM measures were represented. Methodological quality of included studies varied considerably. The 0 - to 6 weeks post-operative meta-analysis showed no statistically significant change in PFM function (SMD = $0.04,95 \% \mathrm{CI}=-0.26$ to 0.33 ). This was consistent at 3 and 6 or more months (SMD = $1.13,0.3595 \%$ CI $=-0.34$ to $2.60,-0.42$ to 1.12 respectively). None of the included studies investigated the relationship between PFM measures and clinician-reported objective outcomes post-operatively.

4) Conclusions: This review did not show a clear effect of POP and/or continence surgery on PFM morphometry or function in women and was unable to show a relationship with outcomes such as objective prolapse score and urodynamic findings. 
This could be because surgery does not measurably impact on the PFM or due to the poor quality and heterogeneity of studies. Future well-designed research is needed to specifically investigate change in the PFM following surgery.

\section{KEYWORDS}

Gynecologic surgical procedures; urologic surgical procedures; colorectal surgery; pelvic floor disorders

\section{INTRODUCTION}

Pelvic floor dysfunction (PFD) is a highly prevalent and burdensome problem for women worldwide. The lifetime risk of undergoing surgery for pelvic organ prolapse or urinary incontinence (POP/UI) in women is $11-19 \%$, and this is expected to double due to our ageing population. ${ }^{1-3}$ Historically, surgical success has been defined by clinician reported objective outcomes, such as urodynamic studies for $\mathrm{UI}^{4}$ and the POP Quantification System for vaginal prolapse. ${ }^{5}$ The long-term outcomes following surgical correction of POP are sub-optimal, with anatomical recurrence rates up to $40 \%$ and subsequently high reoperation rates. ${ }^{6,7}$ Even if the anatomical defect is successfully corrected with the surgery, persisting and de novo pelvic floor symptoms may affect women post-operatively ${ }^{8}$ and this may also occur following surgical correction of UI and anal incontinence. ${ }^{4,9,10}$

To improve surgical outcomes, it is important to consider the modifiable factors that may promote PFD post-operatively. Pelvic floor muscle (PFM) dysfunction is one factor implicated in the pathophysiology of PFD. When compared to continent women, women with UI have poorer PFM morphometry and function in terms of 
muscle thickness, strength, endurance and coordination. ${ }^{11-13}$ Reduced PFM strength and endurance has also been demonstrated in women with POP, ${ }^{14,15}$ and POP severity appears to increase with increasing PFM dysfunction. ${ }^{16,17}$ Weak PFM strength and wide genital hiatus have been linked with poorer POP quantification scores in women with POP/UI both pre- and post-operatively, ${ }^{18,19}$ and have been shown to be risk factors for POP reoperation. ${ }^{19}$ It is therefore important to consider the impact POP/continence surgery has on PFM morphometry and function. If the surgery results in PFM inhibition, weakness or atrophy, then post-operative management that maximises PFM function becomes critical. Although peri-operative PFM status may be an important consideration to maximise surgical success, there is currently limited evidence to support peri-operative PFM training as an adjunct to surgery. Several reviews of peri-operative physiotherapy for women undergoing prolapse surgery have highlighted the need for large, well-designed trials to evaluate the efficacy of perioperative PFM training. ${ }^{8,20-22}$ Knowledge of the impact of POP/ continence surgery on PFM morphometry and function is sparse, and further data will assist our understanding of the natural recovery in myofascial support and may provide further insights into why peri-operative PFM training interventions may or may not work.

The primary aim of this systematic review was to determine what impact, if any, POP/continence surgery has on a woman's PFM morphometry and function postoperatively. The secondary aim was to examine the relationship between postoperative PFM function and POP quantification or urodynamic outcomes. For the primary aim, our hypothesis was that PFM morphometry and function does not change with continence and POP surgery. The hypothesis for the secondary aim was that a positive association might exist between better post-operative PFM function and morphometry and better POP-Q and urodynamic findings.

This article is protected by copyright. All rights reserved. 


\section{MATERIALS AND METHODS}

\subsection{Search strategy}

Electronic databases were searched from the earliest available date until March 2018 (MEDLINE, CINAHL, PEDro, AMED, Embase, and the Cochrane Library). Reference lists of all included articles were manually searched and citations of all included articles were tracked using Google Scholar.

The search strategy focussed on synonyms and MeSH subject headings of the key concepts of continence and pelvic organ prolapse surgery combined with the primary outcomes of pelvic floor muscle function or pelvic floor morphometry. An example of the search strategy as applied in MEDLINE can be viewed in Appendix 1.

\subsection{Eligibility criteria}

All articles were independently assessed by two reviewers using pre-determined eligibility criteria (Appendix 2). Full text copies of studies that could not be clearly included or excluded based on title and abstract were reviewed. Authors were contacted when further detail was required. If consensus could not be reached between the two reviewers, a third reviewer was consulted.

We included either randomised controlled trials or observational studies that examined the effect of POP/continence surgery on the PFM in women. As we sought to investigate the natural history of surgical effects on the PFM, PFM data from participant groups who underwent structured peri-operative PFM training were excluded. Any surgery that directly affected the anal sphincter complex was excluded, due to the confounding effect this would have on anal sphincter manometry data. Only outcome measures that specifically assessed PFM morphometry or function, 
either at rest or on PFM contraction were included. Measures of PFM function may have included digital muscle testing, vaginal or anal squeeze pressure, surface electromyography or dynamometry. Morphometric measures were typically recorded on ultrasound or magnetic resonance imaging and may have included measures of the levator hiatus, anorectal angle, pubococcygeal line, urethrovesical junction, H-line or M-line. Studies were excluded if either baseline pre-operative PFM measures or postoperative comparison scores were not reported, or if there were incomplete data sets (must report for at least 75\%), and this information was unable to be obtained from authors.

\subsection{Quality assessment}

The methodological quality of the included studies was appraised independently by two reviewers using a modified Downs and Black checklist (Appendix 3) ${ }^{23}$ as this checklist could be applied to the study designs included in this review. This quality assessment tool comprises 27 questions, divided into four sections: reporting; external validity; internal validity - bias; and internal validity - confounding (selection bias). No single-group studies scored on items 14, 15, 23 and 24, as these four items are specific to the management of control groups. Therefore, the highest achievable score was 28 points for a controlled study and 24 for a single-group study, with a higher score indicating higher methodological quality. The Downs and Black checklist has been shown to have good test-retest $(r=0.88)$ and inter-rater $(r=0.75)$ reliability. $^{23}$ Discrepancies in quality scores were resolved by discussion between the two reviewers, and a third reviewer was consulted if consensus could not be reached. Studies were not excluded based on quality, but the quality of the study was taken into account when interpreting the results.

This article is protected by copyright. All rights reserved. 


\subsection{Data extraction}

A customised form was developed for data extraction based on recommendations from the Cochrane Handbook for Systematic Reviews of Interventions (2011) (Appendix 4). The form was used to record participant characteristics (age, BMI, parity, delivery mode, previous pelvic surgery, hormone status, previous PFMT, presence of levator avulsion), surgical intervention details, outcome measures used, and detailed PFM results of the studies. Data extraction was completed independently by two reviewers.

\subsection{Data analysis}

To enable comparisons between studies a standardised mean difference with $95 \%$ confidence interval was calculated for all pre-post PFM data. ${ }^{24}$ When the standard deviation of the change was not reported and was not able to be obtained from authors, this information was imputed using the baseline standard deviation where available, otherwise outcome measure data from a similar study was used. ${ }^{25}$ Where studies reported change in PFM measures with non-parametric data, this was converted to mean and standard deviation according to a published formula. ${ }^{26}$ Three meta-analyses were planned to evaluate change in the PFM at different times postoperatively based on stages of tissue healing: up to six weeks, at three months, and six or more months. Within these forest plots the data were presented according to different surgical approaches. Two studies ${ }^{27,28}$ each presented data for two participant groups. In each study, these groups demonstrated homogeneity (i.e. had the same indication for surgery and the surgical procedures were in the same compartment) and were therefore collapsed and represented by a single effect size for each study. Metaanalysis was completed if a minimum of two trials were homogenous in terms of 
surgical approach and outcome measurement tool. To account for heterogeneity, a pooled random effects model was applied using RevMan 5.3. Statistical heterogeneity was assessed by calculating the $\mathrm{I}^{2}{ }^{25}$ To ensure that each participant was represented only once in the meta-analysis, a single outcome measure that best represented the PFM outcome of interest was selected from each study when more than one outcome of interest was presented. Squeeze pressure manometry is considered a more reliable measure of PFM function than digital palpation scales and surface electromyography, ${ }^{29}$ therefore manometry measures were prioritised for inclusion in meta-analyses. The Grades of Research, Assessment, Development and Evaluation (GRADE) approach ${ }^{30}$ was used to assess the quality of evidence obtained for each outcome in this review.

\section{RESULTS}

\subsection{Study selection}

The electronic database search yielded 6,648 records, and one record was found via citation tracking. After duplicates were removed, 3,447 remained, and 3,353 were excluded after screening title and abstract against the inclusion criteria. The full text of 94 records were assessed for eligibility, of which 21 studies were selected for inclusion in the review (Fig. 1).

\subsection{Study characteristics}

3.2.1 Methods Five randomised controlled trials ${ }^{31-35}$, 14 prospective cohort studies $^{27,28,36-47}$ and two retrospective cohort studies ${ }^{48,49}$ were included (Table 1).

3.2.2 Participant characteristics This review included 1,063 female participants who received POP/UI surgery with usual care. Participants were aged from 28 to 83 years 
(Table 1). Body Mass Index was reported in 62\% of the studies with a mean of 26.1 $\mathrm{kg} / \mathrm{m}^{2}$. Participants were of mixed parity (range $0-15$ ), and mode of delivery. In eight studies, ${ }^{31-33,36,43,45,47,49}$ some participants had undergone previous pelvic surgery, with hysterectomy the most common procedure. Participants in six studies had not undergone any previous pelvic surgery..$^{27,37,41,42,46,48}$ Only three studies reported participants’ previous experience with PFM training: in one study participants had no prior PFM training; ${ }^{46}$ in another study 9\% had completed PFM training before participation in the study; ${ }^{40}$ and in a third study over 59\% had done previous PFM training. ${ }^{32}$ A single study reported the presence of levator avulsion pre-operatively. ${ }^{49}$

3.2.3 Interventions A wide range of surgical interventions was represented in the studies (Table 2). Three studies investigated procedures for $\mathrm{UI}^{27,39,45}$ and 12 studies reported on vaginal prolapse repair..$^{28,32,34,37,40-44,46-48}$ Combined POP/UI procedures were performed in four studies..$^{31,33,35,49}$ One study reported perineal levatorplasty and transrectal repair surgery to correct anterior rectocele. ${ }^{36}$ Finally, one study investigated the effect of combined vaginal POP and rectal prolapse procedures. ${ }^{38}$

3.2.4 Methodological quality The quality of the 21 included studies according to the modified Downs and Black criteria varied. Scores ranged from 12 to 26 (median $=21$ out of 28 for controlled/cohort studies and 15 out of 24 for single-cohort studies) (Appendix 5). None of the trials reported blinded participants. Only five studies presented sufficient description of principal confounders or adequate adjustment for confounding in the analysis. ${ }^{31,32,37,40,48}$ A sample size calculation was completed in five studies, ${ }^{31-34,40}$ and only one of these studies had PFM function as their primary outcome measure. ${ }^{40}$

This article is protected by copyright. All rights reserved. 
3.2.5 Pelvic floor muscle measurements There were 33 different PFM measures reported across the studies (Table 2). Strength was most commonly assessed; using the Modified Oxford Grading Scale in eight studies; ${ }^{27,31,32,34,35,37,40,41}$ vaginal squeeze pressure manometry was used in four studies; ${ }^{32,33,40,44}$ and anorectal squeeze pressure manometry was used in four studies..$^{28,36,38,47}$ Three studies assessed PFM myoelectrical activity with surface electromyography. ${ }^{35,37,46}$ Pelvic floor muscle endurance was measured by digital palpation to time the length of hold of a maximum voluntary PFM contraction in two studies. ${ }^{27,34}$ Pelvic floor muscle morphometry was assessed in six studies; four studies used transperineal ultrasound ${ }^{42,43,48,49}$ and two used magnetic resonance imaging..$^{39,45}$

\subsection{Change in PFM morphometry and function post-operatively}

3.3.1 Zero to six weeks The change in PFM function between pre-surgery and 0-6 weeks is illustrated in Figure 2a, grouped according to surgical procedure. When pooled for analysis there was no significant change in PFM function post-operatively according to vaginal manometric measurement $(\mathrm{SMD}=0.04,95 \% \mathrm{CI}=-0.26$ to 0.33). The GRADE quality of evidence for this meta-analysis was low (Appendix 6).

3.3.2 At three months The change in PFM function from pre-surgery to 3 months is illustrated in Figure 2b, grouped according to surgical approach. It was not possible to pool all data for meta-analysis due to significant heterogeneity. When change in PFM strength on Modified Oxford Grading Scale was pooled for analysis, no significant change was observed following vaginal repair $(\mathrm{SMD}=1.13,95 \% \mathrm{CI}=-0.34$ to 2.60$)$. The overall trend indicated that most studies reported no change in PFM function. The average quality score across these studies was 19 out of 28 . The studies that showed a positive change in PFM function post-operatively had an average quality score of 14 
out of 28. The GRADE quality of evidence for this was analysis was moderate (Appendix 6).

3.3.3 Six months and beyond The change in PFM morphometry and function between pre-surgery and six or more months is represented in Figure 2c, grouped according to surgical approach. It was not possible to pool all data for meta-analysis due to significant heterogeneity. When change in PFM function according to a digital palpation scale was pooled for analysis, no significant change was observed following vaginal repair with or without a urethral sling $(\mathrm{SMD}=0.35,95 \% \mathrm{CI}=-0.42$ to 1.12 ). Overall most studies reported no change in PFM morphometry and function. Across these studies the average quality score for controlled/cohort studies was 21 out of 28, and 17 out of 24 for single cohort studies. The studies that showed a positive change in PFM measures post-operatively had a quality score of 14 or less. The GRADE quality of evidence for this analysis was very low (Appendix 6).

\subsection{Association between PFM function and POP Quantification System / urodynamic studies}

Ten of the included studies reported both PFM measures and POP quantification data

pre- and post-operatively. ${ }^{28,31,34,35,37,43,44,46,48,49}$ Association between these two outcomes was not investigated in these studies. None of the studies reported associations between urodynamic findings and PFM measures.

\section{DISCUSSION}

This review sought to determine the impact of POP/continence surgery on women's PFM morphometry and function. Meta-analysis at 0-6 weeks showed no statistically significant change in PFM function post vaginal repair surgery. However, the GRADE rating of this evidence was low and based on few studies. Meta-analysis at 
three months also showed no statistically significant change in PFM function post vaginal repair surgery, the GRADE rating of this evidence was moderate. At six or more months no statistically significant change in PFM function post vaginal repair with or without urethral sling was observed on meta-analysis. The GRADE rating of this evidence was very low. Changes in PFM morphometry were not investigated by any study from pre-surgery to 0-6 weeks or to three months. Due to the heterogeneity in morphometric measures reported by studies at six or more months, it is not possible to determine the impact of surgery on PFM morphometry.

The findings of this review suggest that there is no impact - improvement or deterioration - on PFM function as a result of POP/UI surgery. Given this, and the current lack of evidence to support peri-operative PFM training, ${ }^{22,50}$ we may need to be guided by findings from studies that have shown strong association between poorer pre-operative PFM status and poorer post-operative PFM function. ${ }^{18,19,51-53}$ Therefore, focusing intervention on women with poor PFM function pre-operatively, who are most likely to respond ${ }^{19,51,53}$ may be the best approach to achieve more effective outcomes from peri-operative PFM interventions. This would need to be confirmed with high quality randomised controlled trials.

It is possible and highly likely that the reason we did not find a change in PFM measures as a result of POP/UI surgery, is because of a lack of sensitivity in current PFM measurement tools. Few of the reported measures within this review have been shown to be valid measures of PFM morphometry or function, or demonstrate sufficient reliability and responsiveness to measure small or clinically significant changes in PFM function that may be evident with surgery. An additional reason that 
we found no change in PFM function post-operatively may be due to the fact that only one study was powered to detect a change in PFM morphometry or function. ${ }^{40}$

Without confidently knowing the effect of surgery on PFM morphometry and function, it is difficult to conclude that peri-operative PFM training is required, and if so, when it would be most beneficial. The most recent reviews of peri-operative PFM training for women undergoing prolapse surgery ${ }^{22,50}$ found no significant improvement in prolapse symptoms, degree of prolapse or quality of life with the addition of PFM training. A possible reason for the lack of clear effect in both of these reviews and this one could be that women with poorer pre-operative PFM function $^{18,19,51-53}$ (at risk group), were not specifically targeted.

A clear understanding of the relationship between changes in PFM measures postoperatively and symptom recurrence is challenging without accurate PFM measurement. There is some evidence that demonstrates a positive association between POP recurrence and reduced PFM strength and a widened genital hiatus. ${ }^{18,19}$ Further evaluation of these associations was not possible in this review, as the included studies did not investigate such correlations.

There are several limitations of this review and the interpretations we have made from the findings that need to be considered. First, articles not published in English were excluded, potentially leading to selection bias. Secondly, conclusions made are based on the generally poor or moderate methodological quality of the included studies. Studies did not adequately report or control for confounding factors such as levator avulsion, ${ }^{54}$ participant's activity levels or exercise, ${ }^{55}$ weight gain or loss, ${ }^{56-58}$ or hormonal fluctuations ${ }^{59,60}$ that may also affect PFM function. Thirdly, the heterogeneity of surgical interventions limited our ability to draw firm conclusions 
about the impact of any particular surgical approach on PFM measures. Fourthly, for morphometric measures it is not possible to differentiate change in the contractile versus non-contractile tissue, therefore it is uncertain whether change in PFM morphometry on PFM contraction post-operatively represents a change in the connective tissue length, or change in the contractile activity of the muscles or a combination of the two. Lastly, the overall rating of the evidence using GRADE was low.

Future research is required that (i) is powered to detect a difference in PFM morphometry or function between groups; (ii) employs outcome measures that are highly reliable and responsive to change; (iii) adequately controls for known confounders that may influence PFM outcome; (iv) and includes assessment of PFM function up to 5 years after initial surgery to capture the association between better PFM morphometry or strength and better post-operative symptom outcomes.

\section{CONCLUSIONS}

Synthesis of studies within this review showed absence of a clear impact of POP/UI surgery on PFM function or morphometry in women. This could be because surgery does not measurably impact on PFM function in the short and medium term, and therefore is unlikely to in the longer term, or be due to the poor quality and heterogeneity of studies. To have greater certainty regarding this question future research that is well-designed to specifically investigate the change in the PFM with surgery is needed. Clinicians may continue to be guided by existing evidence-based recommendations for PFM training in women who present with symptoms of UI or POP, with or without surgical treatment.

This article is protected by copyright. All rights reserved. 


\section{References}

1. Fialkow M, Newton K, Lentz G, Weiss N. Lifetime risk of surgical management for pelvic organ prolapse or urinary incontinence. Int Urogynecol J. 2008;19(3):437-440.

2. Smith FJ, Holman CAJ, Moorin RE, Tsokos N. Lifetime risk of undergoing surgery for pelvic organ prolapse. Obstet Gynecol. 2010;116(5):1096-1100.

3. Olsen AL, Smith VJ, Bergstrom JO, Colling JC, Clark AL. Epidemiology of Surgically Managed Pelvic-Organ Prolapse and Urinary Incontinence. Obstet Gynecol. 1997;89(4):501-506.

4. Rovner E, Athanasiou S, Choo MS, et al. Surgery for unrinary incontinence in women. In: Abrams P, Cardozo L, Wein A, Wagg A, eds. Incontinence. 6th ed. Tokyo: International Continence Society; 2017:1741-1854.

5. Maher C, Baessler K, Barber M, et al. Pelvic organ prolapse surgery. In: Abrams P, Cardozo L, Wein A, Wagg A, eds. Incontinence. 6th ed. Tokyo: International Continence Society; 2017:1855-1991.

6. Luber KM, Boero S, Choe JY. The demographics of pelvic floor disorders: current observations and future projections. Am J Obstet Gynecol. 2001;184(7):1496-1503.

7. Miedel A, Tegerstedt G, Mörlin B, Hammarström M. A 5-year prospective follow-up study of vaginal surgery for pelvic organ prolapse. Int Urogynecol J. 2008;19(12):1593-1601.

8. Lakeman MM, Koops SES, Berghmans BC, Roovers JPW. Peri-operative physiotherapy to prevent recurrent symptoms and treatment following prolapse surgery: supported by evidence or not? Int Urogynecol $J$. 2013;24(3):371-375.

9. Ford AA, Rogerson L, Cody JD, Aluko P, Ogah JA. Mid-urethral sling operations for stress urinary incontinence in women. Cochrane Database Syst Rev. 2017(7).

10. O'Connell PR, Knowles CH, Maeda Y, et al. Surgery for faecal incontinence. In: Abrams P, Cardozo L, Wagg A, Wein A, eds. Incontinence. 6th ed. Tokyo: International Continence Society; 2017:2087-2142.

11. Devreese A, Staes F, De Weerdt W, et al. Clinical evaluation of pelvic floor muscle function in continent and incontinent women. Neurourol Urodyn. 2004;23(3):190-197.

12. Morin M, Bourbonnais D, Gravel D, Dumoulin C, Lemieux MC. Pelvic floor muscle function in continent and stress urinary incontinent women using dynamometric measurements. Neurourol Urodyn. 2004;23(7):668-674.

13. Oliveira E, Castro RA, Takano CC, et al. Ultrasonographic and Doppler velocimetric evaluation of the levator ani muscle in premenopausal women

This article is protected by copyright. All rights reserved. 
with and without urinary stress incontinence. Eur J Obstet Gynecol Reprod Biol. 2007;133(2):213-217.

14. Braekken I, Majida M, Ellström Engh M, Holme I, Bø K. Pelvic floor function is independently associated with pelvic organ prolapse. BJOG. 2009;116(13):1706-1714.

15. DeLancey JO, Morgan DM, Fenner DE, et al. Comparison of levator ani muscle defects and function in women with and without pelvic organ prolapse. Obstet Gynecol. 2007;109(2):295-302.

16. Chen L, Ashton-Miller JA, Hsu Y, DeLancey J. Interaction among apical support, levator ani impairment, and anterior vaginal wall prolapse. Obstet Gynecol. 2006;108(2):324-332.

17. DeLancey JO. The hidden epidemic of pelvic floor dysfunction: achievable goals for improved prevention and treatment. Am J Obstet Gynecol. 2005;192(5):1488-1495.

18. Borello-France DF, Handa VL, Brown MB, et al. Pelvic-floor muscle function in women with pelvic organ prolapse. Phys Ther. 2007;87(4):399-407.

19. Vakili B, Zheng YT, Loesch H, Echols KT, Franco N, Chesson RR. Levator contraction strength and genital hiatus as risk factors for recurrent pelvic organ prolapse. Am J Obstet Gynecol. 2005;192(5):1592-1598.

20. Dumoulin C, Adewuyi T, Booth J, et al. Adult Conservative Management. In: Abrams P, Cardozo L, eds. Incontinence. 6th ed. Tokyo: International Continence Society; 2017:1443-1628.

21. Hagen S, Stark D. Conservative prevention and management of pelvic organ prolapse in women. Cochrane Database Syst Rev. 2011(12).

22. Haya N, Feiner B, Baessler K, Christmann-Schmid C, M aher C. Perioperative interventions in pelvic organ prolapse surgery. Cochrane Database Syst Rev. 2018(8).

23. Downs SH, Black N. The feasibility of creating a checklist for the assessment of the methodological quality both of randomised and non-randomised studies of health care interventions. J Epidemiol Community Health. 1998;52(6):377384.

24. Lakens D. Calculating and reporting effect sizes to facilitate cumulative science: a practical primer for t-tests and ANOVAs. Front Psychol. 2013;4:863.

25. Higgins JPT, Green S. Cochrane Handbook for Systematic Review Interventions The Cochrane Collaboration; 2011: http://handbook.cochrane.org.

This article is protected by copyright. All rights reserved. 
26. Wan X, Wang W, Liu J, Tong T. Estimating the sample mean and standard deviation from the sample size, median, range and/or interquartile range. $B M C$ Med Res Methodol. 2014;14(1):135.

27. Beilecke K, Soeder S, Hufenbach E, Tunn R. Impact of Retropubic vs. Transobturator Slings for Urinary Incontinence on Myofascial Structures of the Pelvic Floor, Adductor and Abdominal Muscles. Geburtshilfe Frauenheilkd. 2014;74(1):69.

28. Liang S, Zhu L, Zhang L, Sun Z-J, Tao X, Lang J-H. Manometric comparison of anorectal function after posterior vaginal compartment repair with and without mesh. Chin Med J. 2015;128(4):438.

29. Navarro Brazález B, Torres Lacomba M, de la Villa P, et al. The evaluation of pelvic floor muscle strength in women with pelvic floor dysfunction: A reliability and correlation study. Neurourol Urodyn. 2018;37(1):269-277.

30. Guyatt GH, Oxman AD, Kunz R, et al. Rating quality of evidence and strength of recommendations: Going from evidence to recommendations. BMJ. 2008;336(7652):1049.

31. Barber MD, Brubaker L, Burgio KL, et al. Comparison of 2 transvaginal surgical approaches and perioperative behavioral therapy for apical vaginal prolapse: the OPTIMAL randomized trial. JAMA. 2014;311(10):1023-1034.

32. Frawley HC, Phillips BA, Bø K, Galea MP. Physiotherapy as an adjunct to prolapse surgery: An assessor-blinded randomized controlled trial. Neurourol Urodyn. 2010;29(5):719-725.

33. Jarvis SK, Hallam TK, Lujic S, Abbott JA, Vancaillie TG. Peri-operative physiotherapy improves outcomes for women undergoing incontinence and or prolapse surgery: Results of a randomised controlled trial. Aust N Z J Obstet Gynaecol. 2005;45(4):300-303.

34. McClurg D, Hilton P, Dolan L, et al. Pelvic floor muscle training as an adjunct to prolapse surgery: a randomised feasibility study. Int Urogynecol $\mathrm{J}$. 2014;25(7):883-891.

35. Pauls RN, Crisp CC, Novicki K, Fellner AN, Kleeman SD. Pelvic floor physical therapy: impact on quality of life 6 months after vaginal reconstructive surgery. Female Pelvic Med Reconstr Surg. 2014;20(6):334341.

36. Boccasanta P, Venturi M, Cioffi U, et al. Selection criteria and long-term results of surgery in symptomatic rectocele. Minerva Chir. 2002;57(2):157163.

37. Chen X, Gong Y, Wu D, et al. Pre-and postoperative evaluati on of pelvic floor muscle function in POP patients using surface electromyography and digital palpation. Neurourol Urodyn. 2014;33(4):403-407.

This article is protected by copyright. All rights reserved. 
38. Dekel A, Rabinerson D, Rafael ZB, Kaplan B, Mislovaty B, Bayer Y.

Concurrent genital and rectal prolapse: two pathologies-one joint operation. BJOG. 2000;107(1):125-129.

39. Digesu G, Bombieri L, Hutchings A, Khullar V, Freeman R. Effects of Burch colposuspension on the relative positions of the bladder neck to the levator ani muscle: an observational study that used magnetic resonance imaging. Am $J$ Obstet Gynecol. 2004;190(3):614-619.

40. Duarte TB, Bonacin MA, Brito LG, et al. Does pelvic floor muscle maximum voluntary contraction improve after vaginal pelvic organ prolapse surgery? A prospective study. Neurourol Urodyn. 2018.

41. Guan Z, Li H-F, Yang X, Guo L-L. Pelvic reconstruction improves pelvic floor strength in pelvic organ prolapse patients. Taiwan J Obstet Gynecol. 2015;54(5):519-521.

42. Hanzal E, Berger E, Koelbl H. Levator ani muscle morphology and recurrent genuine stress incontinence. Int J Gynecol Obstet. 1993;43(2):235-235.

43. Lone F, Thakar R, Sultan AH, Stankiewicz A. Prospective evaluation of change in levator hiatus dimensions using 3D endovaginal ultrasound before and 1 year after treatment for female pelvic organ prolapse. Int Urogynecol J. 2013;24(8):1287-1293.

44. Mouritsen L, Hulbæk M, Brostrøm S, Bogstad J. Vaginal pressure during daily activities before and after vaginal repair. Int Urogynecol $J$. 2007;18(8):943-948.

45. Rinne K, Kainulainen S, Aukee S, Heinonen S, Nilsson CG. Dynamic MRI confirms support of the mid-urethra by TVT and TVT - O surgery for stress incontinence. Acta Obstet Gynecol Scand. 2011;90(6):629-635.

46. Wang L, Chen X, Li X, Gong Y, Li H, Tong X. The improvement of pelvic floor muscle function in POP patients after the Prolift procedure: results from surface electromyography. Int Urogynecol J. 2013;24(10):1703-1708.

47. Yamana T, Takahashi T, Iwadare J. Clinical and physiologic outcomes after transvaginal rectocele repair. Dis Colon Rectum. 2006;49(5):661-667.

48. Huang WC, Yang SH, Yang JM. Pelvic floor muscle functions are improved after successful transobturator vaginal mesh procedures. Neurourol Urodyn. 2017;36(2):380-384.

49. Andrew BP, Shek KL, Chantarasorn V, Dietz HP. Enlargement of the levator hiatus in female pelvic organ prolapse: cause or effect? A $N Z$ J Obstet Gynaecol. 2013;53(1):74-78.

50. Zhang FW, Wei F, Wang HL, et al. Does pelvic floor muscle training augment the effect of surgery in women with pelvic organ prolapse? A systematic review of randomized controlled trials. Neurourol Urodyn. 2016;35(6):666674.

This article is protected by copyright. All rights reserved. 
51. Friedman T, Eslick GD, Dietz HP. Risk factors for prolapse recurrence: systematic review and meta-analysis. Int Urogynecol J. 2017:1-9.

52. Rodrigo N, Wong V, Shek KL, Martin A, Dietz HP. The use of 3dimensional ultrasound of the pelvic floor to predict recurrence risk after pelvic reconstructive surgery. Aust N Z J Obstet Gynaecol. 2014;54(3):206211.

53. Schachar JS, Devakumar H, Martin L, Farag S, Hurtado EA, Davila GW. Pelvic floor muscle weakness: a risk factor for anterior vaginal wall prolapse recurrence. Int Urogynecol J. 2018:1-7.

54. Dietz H, Shek C. Levator avulsion and grading of pelvic floor muscle strength. Int Urogynecol J. 2008;19(5):633-636.

55. Nygaard IE, Shaw JM. Physical activity and the pelvic floor. Am J Obstet Gynecol. 2016;214(2):164-171.

56. Imamura M, Williams K, Wells M, McGrother C. Lifestyle interventions for the treatment of urinary incontinence in adults. Cochrane Database Syst Rev. 2015.

57. Ramalingam K, Monga A. Obesity and pelvic floor dysfunction. Best Pract Res Clin Obstet Gynaecol. 2015;29(4):541-547.

58. Vergeldt TF, Weemhoff M, IntHout J, Kluivers KB. Risk factors for pelvic organ prolapse and its recurrence: a systematic review. Int Urogynecol J. 2015;26(11):1559-1573.

59. Legendre G, Ringa V, Fauconnier A, Fritel X. Menopause, hormone treatment and urinary incontinence at midlife. Maturitas. 2013;74(1):26-30.

60. Reay Jones N, Healy J, King L, Saini S, Shousha S, Allen-M ersh T. Pelvic connective tissue resilience decreases with vaginal delivery, menopause and uterine prolapse. BJS Open. 2003;90(4):466-472.

This article is protected by copyright. All rights reserved. 


\section{Figures}

Figure 1: Flow of information through the systematic review

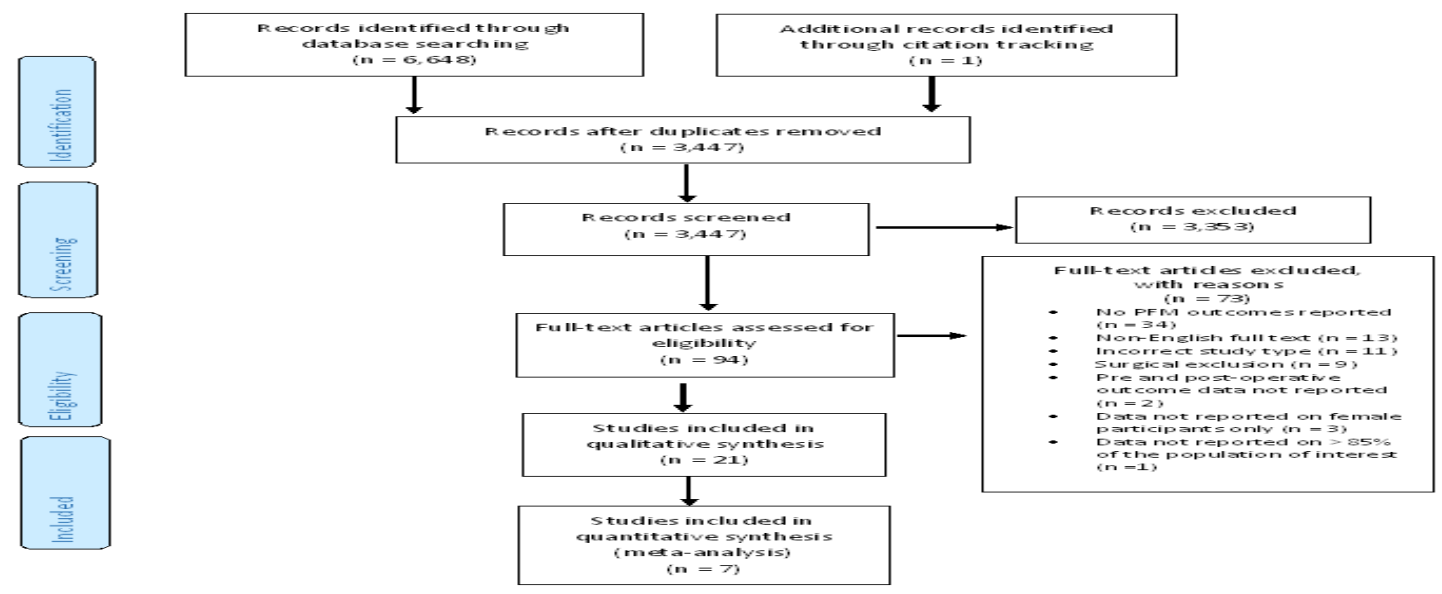

Figure 2: Standardised mean difference (95\% CI) of change in PFM post-operatively.

A. Zero to six weeks B. At three months. C. Six or more months. * Not included due to insufficient data. MOGS = Modified Oxford Grading Scale, VSP = vaginal squeeze pressure, $M V C=$ maximum voluntary contraction, $S E M G=$ surface electrograph, $N R=$ not reported, $A S P=$ anal squeeze pressure, Dist $=$ distance,$L A=$ levator ani, $P C=$ pubococcygeal, $P F M C=$ pelvic floor muscle contraction, BNA = bladder neck angle, LHA = levator hiatal area .

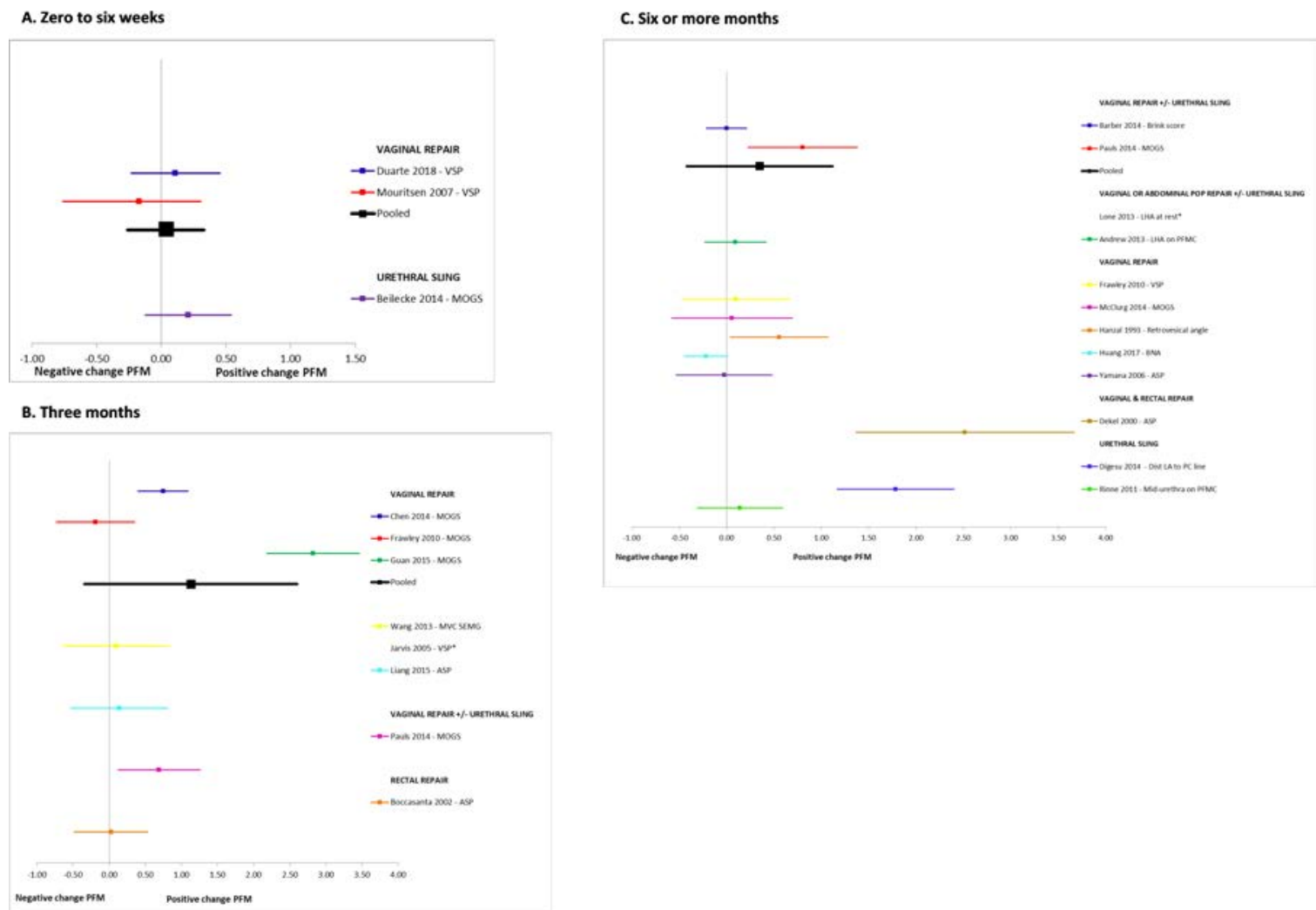

This article is protected by copyright. All rights reserved. 
Table 1. Characteristics of participants

\section{Study \\ (Count Desig Participan \\ ry) n ts}

\begin{tabular}{|c|c|c|c|c|c|c|c|c|c|c|}
\hline & & $\mathbf{n}$ & $\begin{array}{l}\text { Age, } \\
\text { mean } \\
\text { (SD) } \\
\text { [rang } \\
\text { e] }\end{array}$ & $\begin{array}{l}\text { BMI, } \\
\text { mean } \\
\text { (SD) } \\
\text { [range } \\
\text { ] }\end{array}$ & $\begin{array}{l}\text { Pari } \\
\text { ty, } \\
\text { mea } \\
\text { n } \\
\text { (SD) } \\
\text { / } \\
\text { med } \\
\text { ian } \\
\text { [ran } \\
\text { ge] } \\
\end{array}$ & $\begin{array}{l}\text { Vag } \\
\text { inal } \\
\text { deli } \\
\text { veri } \\
\text { es, } \\
\text { mea } \\
\text { n } \\
\text { (SD } \\
\text { ) } \\
\text { [ran } \\
\text { ge] / } \\
\text { n } \\
\text { (\%) }\end{array}$ & $\begin{array}{l}\text { Hor } \\
\text { mon } \\
\text { al } \\
\text { statu } \\
\text { s, n } \\
(\%) \\
\end{array}$ & $\begin{array}{l}\text { Previous } \\
\text { pelvic } \\
\text { surgery, } \\
\text { n }(\%) \text { / } \\
\text { mean } \\
\text { [range] }\end{array}$ & $\begin{array}{l}\text { Pre } \\
\text { vio } \\
\text { us } \\
\text { PF } \\
\text { MT } \\
\text {, n } \\
(\% \\
) \\
\end{array}$ & $\begin{array}{l}\text { Lev } \\
\text { ato } \\
\text { r } \\
\text { avu } \\
\text { lsio } \\
\text { n, n } \\
(\% \\
)\end{array}$ \\
\hline $\begin{array}{l}\text { Andrew } \\
\text { et al., } \\
2013 \\
\text { (Australia } \\
\text { ) }\end{array}$ & $\begin{array}{l}\text { Retrosp } \\
\text { ective } \\
\text { Cohort } \\
\text { Study }\end{array}$ & 81 & $\begin{array}{l}60.2 \\
(11.1)\end{array}$ & NR & $\begin{array}{l}3 \text { [1- } \\
10]\end{array}$ & $\begin{array}{l}81 \\
(100 \\
\%)\end{array}$ & NR & $\begin{array}{l}\text { TAH/VH } 37 \\
(46 \%) ; \\
\text { POP/contine } \\
\text { nce surg } 17 \\
(21 \%)\end{array}$ & NR & $\begin{array}{l}24 \\
(29.6 \\
\%)\end{array}$ \\
\hline \multirow[t]{2}{*}{$\begin{array}{l}\text { Barber et } \\
\text { al., } 2014 \\
\text { (USA) }\end{array}$} & RCT & $\begin{array}{l}\text { Exp } \\
= \\
186\end{array}$ & $\begin{array}{l}57.5 \\
(10.9) \\
{[29-80]}\end{array}$ & $\begin{array}{l}29.3 \\
(5.6) \\
{[19.3-} \\
49.8]\end{array}$ & $\begin{array}{l}\text { media } \\
\text { n } 3[0- \\
15]\end{array}$ & $\begin{array}{l}186 \\
(100 \\
\%)\end{array}$ & $\begin{array}{l}\text { Pre } \\
\text { mp } 50 \\
(26.9 \\
\%) ; \\
\text { Post } \\
\text { mp } \\
123 \\
(66.1 \\
\%) ; \text { on } \\
\text { HRT } \\
64 \\
(35.4 \\
\%)\end{array}$ & $\begin{array}{l}\text { hyst } 45 \\
\text { (24.2\%); } \\
\text { SUI surg } 6 \\
\text { (3.2\%); POP } \\
\text { surg 9 } \\
(4.8 \%)\end{array}$ & NR & NR \\
\hline & & $\begin{array}{l}\text { Con } \\
= \\
188\end{array}$ & $\begin{array}{l}56.9 \\
(10.90) \\
{[31-80]}\end{array}$ & $\begin{array}{l}28.4 \\
(5.3) \\
{[19.7-} \\
46.3]\end{array}$ & $\begin{array}{l}\text { media } \\
\text { n } 3[0- \\
12]\end{array}$ & $\begin{array}{l}188 \\
(100 \\
\%)\end{array}$ & $\begin{array}{l}\text { Pre } \\
\text { mp } 56 \\
(29.8 \\
\%) ; \\
\text { Post } \\
\text { mp } \\
123 \\
(65.4 \\
\%) ; \text { on } \\
\text { HRT } \\
70 \\
(37.3 \\
\%) \\
\end{array}$ & $\begin{array}{l}\text { hyst } 55 \\
\text { (29.3\%); } \\
\text { SUI surg } 7 \\
\text { (3.7\%); POP } \\
\text { surg 17 } \\
(9.0 \%)\end{array}$ & NR & \\
\hline $\begin{array}{l}\text { Beilecke } \\
\text { et al., } \\
2014 \\
\text { (Germany } \\
\text { ) }\end{array}$ & $\begin{array}{l}\text { Prospect } \\
\text { ive } \\
\text { Cohort } \\
\text { Study } \\
\text { Gp } 1\end{array}$ & $\begin{array}{l}\mathrm{Gp} \\
1= \\
33\end{array}$ & 68 & 26 & NR & NR & NR & $\begin{array}{l}\text { no previous } \\
\text { urogynae } \\
\text { surg }\end{array}$ & NR & NR \\
\hline
\end{tabular}

This article is protected by copyright. All rights reserved. 


\begin{tabular}{|c|c|c|c|c|c|c|c|c|c|c|}
\hline & $\begin{array}{l}\text { Retropu } \\
\text { bic }\end{array}$ & & & & & & & & & \\
\hline & $\begin{array}{l}\text { Gp } 2 \\
\text { Transob } \\
\text { turator }\end{array}$ & $\begin{array}{l}\mathrm{Gp} \\
2= \\
37\end{array}$ & 65 & 25 & NR & NR & NR & $\begin{array}{l}\text { no previous } \\
\text { urogynae } \\
\text { surg }\end{array}$ & NR & \\
\hline $\begin{array}{l}\text { Boccasan } \\
\text { ta et al., } \\
2002 \\
\text { (Italy) }\end{array}$ & $\begin{array}{l}\text { Prospect } \\
\text { ive } \\
\text { Cohort } \\
\text { Study }\end{array}$ & 30 & $\begin{array}{l}52.9 \\
{[28-70]}\end{array}$ & NR & $\begin{array}{l}16 \\
(53.3 \\
\%) \\
\text { multip } \\
\text { arous }\end{array}$ & NR & NR & $\begin{array}{l}8(26.6 \%) \\
\text { hyst }\end{array}$ & NR & NR \\
\hline \multirow[t]{2}{*}{$\begin{array}{l}\text { Chen et } \\
\text { al., } 2014 \\
\text { (China) }\end{array}$} & $\begin{array}{l}\text { Prospect } \\
\text { ive } \\
\text { Cohort } \\
\text { Study }\end{array}$ & $\begin{array}{l}\text { Exp } \\
=74\end{array}$ & $\begin{array}{l}69.31 \\
(9.46)\end{array}$ & $\begin{array}{l}23.52 \\
(2.72)\end{array}$ & NR & $\begin{array}{l}\leq 1: \\
15(20 \\
.3 \%) ; \\
2-3: \\
43(58 \\
.1 \%) ; \\
\geq 4: \\
16(21 \\
.6 \%)\end{array}$ & $\begin{array}{l}\text { Pre } \\
\text { mp: } \\
6(8.1 \\
\%) ; \\
\text { Peri } \\
\text { mp: } \\
5(6.8 \\
\%) ; \\
\text { Post } \\
\text { mp: } \\
63(85 . \\
1 \%) ; \\
\text { on } \\
\text { HRT: } \\
14(18 . \\
9 \%)\end{array}$ & nil & NR & NR \\
\hline & & $\begin{array}{l}\text { Con } \\
=30\end{array}$ & $\begin{array}{l}67.37 \\
(5.56)\end{array}$ & $\begin{array}{l}23.94 \\
(3.06)\end{array}$ & NR & $\begin{array}{l}\leq 1: \\
7(23 . \\
3 \%) ; \\
2-3: \\
14(46 \\
.7 \%) ; \\
\geq 4: \\
9(30 \\
\%)\end{array}$ & $\begin{array}{l}\text { Pre } \\
\text { mp: } \\
3(10 \% \\
) \text {; Peri } \\
\text { mp: } \\
3(10 \% \\
) \text {; Post } \\
\text { mp: } \\
24(80 \\
\%) ; \text { on } \\
\text { HRT: } \\
7(23.3 \\
\%) \\
\end{array}$ & nil & NR & \\
\hline $\begin{array}{l}\text { Dekel et } \\
\text { al., } 2000 \\
\text { (Israel) }\end{array}$ & $\begin{array}{l}\text { Prospect } \\
\text { ive } \\
\text { Cohort } \\
\text { Study }\end{array}$ & 10 & $\begin{array}{l}71.8 \\
{[51-82]}\end{array}$ & NR & $\begin{array}{l}3.2[2- \\
5]\end{array}$ & $\begin{array}{l}2.8 \\
(0.71)\end{array}$ & NR & NR & NR & NR \\
\hline $\begin{array}{l}\text { Digesu et } \\
\text { al., } 2014 \\
\text { (Italy) }\end{array}$ & $\begin{array}{l}\text { Prospect } \\
\text { ive } \\
\text { Cohort } \\
\text { Study }\end{array}$ & 28 & $\begin{array}{l}54 \text { [28- } \\
77]\end{array}$ & NR & $\begin{array}{l}2.1[1- \\
8]\end{array}$ & NR & NR & NR & NR & NR \\
\hline $\begin{array}{l}\text { Duarte et } \\
\text { al., } 2018 \\
\text { (Brazil) }\end{array}$ & $\begin{array}{l}\text { Prospect } \\
\text { ive } \\
\text { Cohort } \\
\text { Study }\end{array}$ & 67 & $\begin{array}{l}62 \\
(10.2)\end{array}$ & $\begin{array}{l}28.7 \\
(5.2)\end{array}$ & $\begin{array}{l}1 \\
\text { nullip, } \\
<540 \\
(61.5 \\
\%), \geq \\
524 \\
(36.9 \\
\%)\end{array}$ & $\begin{array}{l}62 \\
(92.5 \\
\%)\end{array}$ & $\begin{array}{l}\text { Pre } \\
\text { mp } 9 \\
(13.8 \\
\%) \\
\text { Post } \\
\text { mp } 56 \\
(86.1 \\
\%)\end{array}$ & $\begin{array}{l}\text { nil previous } \\
\text { POP surg }\end{array}$ & $\begin{array}{l}6 \\
(9.23 \\
\%)\end{array}$ & NR \\
\hline
\end{tabular}

This article is protected by copyright. All rights reserved. 


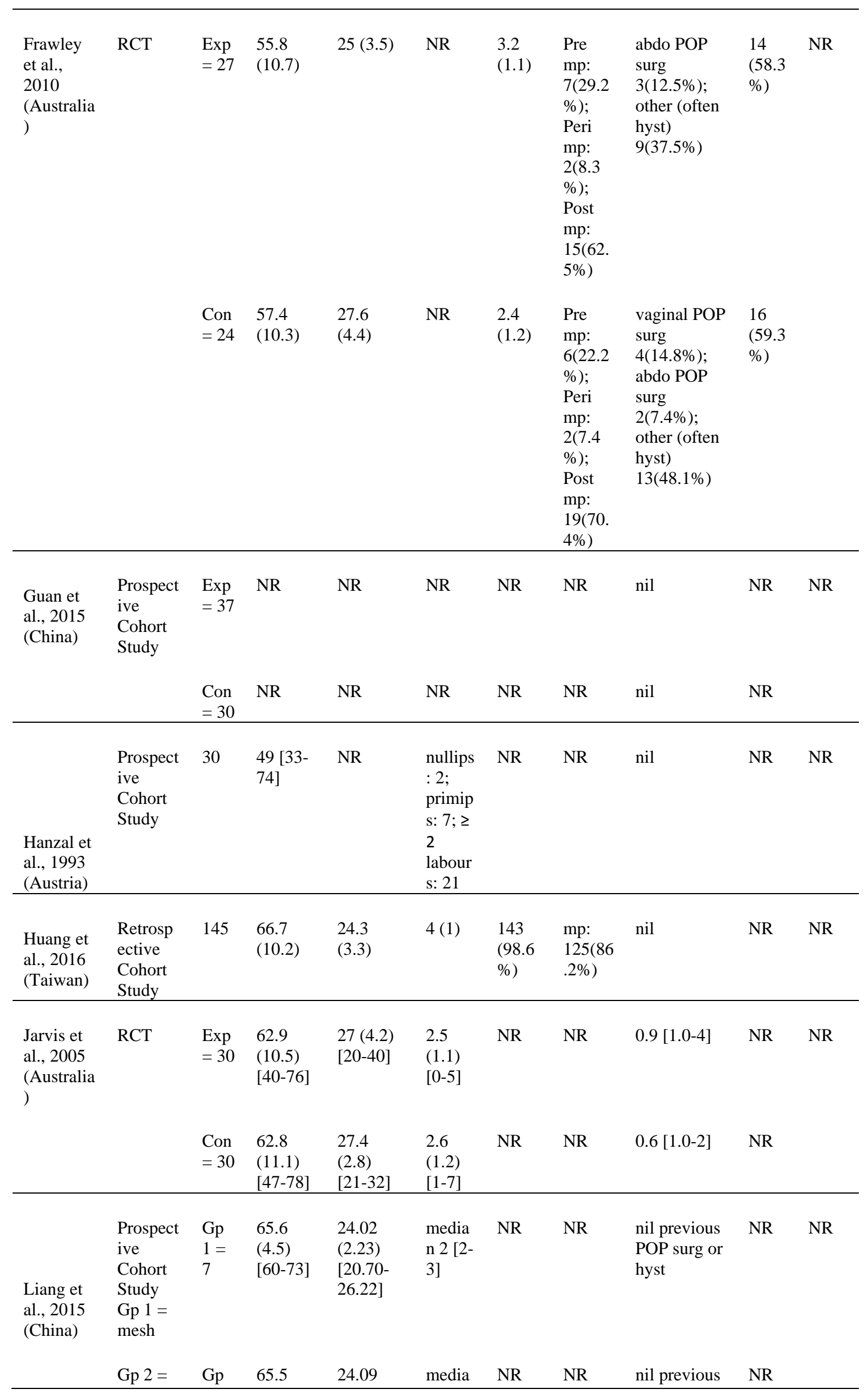

This article is protected by copyright. All rights reserved. 
$\begin{array}{lllll}\text { no mesh } & 2= & (4.8) & (2.93) & \text { n 2 [1- } \\ & 10 & {[56-73]} & {[19.92-} & 3]\end{array}$ 30.02]

\begin{tabular}{|c|c|c|c|c|c|c|c|c|c|c|}
\hline & no mesh & $\begin{array}{l}2= \\
10\end{array}$ & $\begin{array}{l}(4.8) \\
{[56-73]}\end{array}$ & $\begin{array}{l}(2.93) \\
{[19.92-} \\
30.02]\end{array}$ & $\begin{array}{l}\text { n } 2 \text { [1- } \\
3]\end{array}$ & & & $\begin{array}{l}\text { POP surg or } \\
\text { hyst }\end{array}$ & & \\
\hline \multirow[t]{3}{*}{$\begin{array}{l}\text { Lone et } \\
\text { al., } 2013 \\
\text { (United } \\
\text { Kingdom } \\
\text { ) }\end{array}$} & $\begin{array}{l}\text { Prospect } \\
\text { ive } \\
\text { Cohort } \\
\text { Study } \\
\text { Gp 1 = } \\
\text { Surgery }\end{array}$ & $\begin{array}{l}\text { Gp } \\
1= \\
43\end{array}$ & $\begin{array}{l}51.67 \\
(20)\end{array}$ & $\begin{array}{l}29.1 \\
(5.9)\end{array}$ & $\begin{array}{l}\text { media } \\
\text { n } 2[0- \\
6]\end{array}$ & NR & NR & $\begin{array}{l}\text { POP surg } 14 \\
(15.7 \%)\end{array}$ & NR & NR \\
\hline & $\begin{array}{l}\text { Gp } 2= \\
\text { Pessary }\end{array}$ & $\begin{array}{l}\text { Gp } \\
2= \\
10\end{array}$ & $\begin{array}{l}58.14 \\
(15)\end{array}$ & $\begin{array}{l}31.4 \\
(6.3)\end{array}$ & $\begin{array}{l}\text { media } \\
\text { n } 3[0- \\
5]\end{array}$ & NR & NR & $\begin{array}{l}\text { POP surg } 9 \\
(10.1 \%)\end{array}$ & NR & \\
\hline & $\begin{array}{l}\text { Gp } 3= \\
\text { no } \\
\text { treatmen } \\
\mathrm{t}\end{array}$ & $\begin{array}{l}\text { Gp } \\
3= \\
34\end{array}$ & $\begin{array}{l}51.22 \\
(19)\end{array}$ & $30.6(6)$ & $\begin{array}{l}\text { media } \\
\text { n } 2[0- \\
6]\end{array}$ & NR & NR & $\begin{array}{l}\text { POP surg } 12 \\
(13.5 \%)\end{array}$ & NR & \\
\hline \multirow[t]{2}{*}{$\begin{array}{l}\text { McClurg } \\
\text { et al., } \\
2014 \\
\text { (United } \\
\text { Kingdom } \\
\text { ) }\end{array}$} & $\mathrm{RCT}$ & $\begin{array}{l}\text { Exp } \\
=28\end{array}$ & $\begin{array}{l}\text { median } \\
60 \text { [35- } \\
80] \\
\text { both } \\
\text { groups }\end{array}$ & $\begin{array}{l}27(3.0) \\
\text { both } \\
\text { groups }\end{array}$ & $\begin{array}{l}2.19 \\
(0.83) \\
\text { both } \\
\text { groups }\end{array}$ & NR & NR & NR & NR & NR \\
\hline & & $\begin{array}{l}\text { Con } \\
=29 \\
\end{array}$ & & & & NR & NR & NR & NR & \\
\hline $\begin{array}{l}\text { Mouritse } \\
\text { n et al., } \\
2007 \\
\text { (Denmark } \\
\text { ) }\end{array}$ & $\begin{array}{l}\text { Prospect } \\
\text { ive } \\
\text { Cohort } \\
\text { Study }\end{array}$ & 23 & $\begin{array}{l}61.3 \\
{[46-81]}\end{array}$ & $\begin{array}{l}25.0 \\
{[20.1-} \\
40.0]\end{array}$ & NR & NR & NR & $\begin{array}{l}\text { nil POP surg } \\
\text { or hyst }\end{array}$ & NR & NR \\
\hline \multirow[t]{2}{*}{$\begin{array}{l}\text { Pauls et } \\
\text { al., } 2014 \\
\text { (USA) }\end{array}$} & RCT & $\begin{array}{l}\text { Exp } \\
=29\end{array}$ & $\begin{array}{l}58.9 \\
(10.66)\end{array}$ & $\begin{array}{l}28.4 \\
(6.49)\end{array}$ & $\begin{array}{l}3.2 \\
(1.55)\end{array}$ & NR & NR & NR & NR & NR \\
\hline & & $\begin{array}{l}\text { Con } \\
=28 \\
\end{array}$ & $\begin{array}{l}57.1 \\
(10.41) \\
\end{array}$ & $\begin{array}{l}27.6 \\
(3.50) \\
\end{array}$ & $\begin{array}{l}3.39 \\
(1.68) \\
\end{array}$ & NR & NR & NR & NR & \\
\hline \multirow[t]{2}{*}{$\begin{array}{l}\text { Rinne et } \\
\text { al., } 2011 \\
\text { (Finland) }\end{array}$} & $\begin{array}{l}\text { Prospect } \\
\text { ive } \\
\text { Cohort } \\
\text { Study }\end{array}$ & $\begin{array}{l}\text { Exp } \\
=42\end{array}$ & $\begin{array}{l}\text { median } \\
50 \text { [38- } \\
70]\end{array}$ & $\begin{array}{l}\text { median } \\
26 \text { [20- } \\
38]\end{array}$ & $\begin{array}{l}\text { media } \\
\text { n } 2 \text { [1- } \\
7]\end{array}$ & NR & $\begin{array}{l}\text { Post } \\
\text { mp: } \\
\text { 18(45 } \\
\%) ; \text { on } \\
\text { HRT: } \\
\text { 19(47 } \\
\%)\end{array}$ & $\begin{array}{l}\text { hyst } 1 \\
(0.02 \%)\end{array}$ & NR & NR \\
\hline & & $\begin{array}{l}\text { Con } \\
=16\end{array}$ & $\begin{array}{l}\text { median } \\
41 \text { [33- } \\
53]\end{array}$ & $\begin{array}{l}\text { median } \\
24 \text { [20- } \\
28]\end{array}$ & $\begin{array}{l}\text { media } \\
\text { n } 3[2- \\
4]\end{array}$ & NR & $\begin{array}{l}\text { Post } \\
\text { mp: } 4 \\
(27 \%) \text {; } \\
\text { on } \\
\text { HRT: } \\
4 \\
(27 \%)\end{array}$ & nil & NR & \\
\hline $\begin{array}{l}\text { Wang et } \\
\text { al., } 2013 \\
\text { (China) }\end{array}$ & $\begin{array}{l}\text { Prospect } \\
\text { ive } \\
\text { Cohort } \\
\text { Study }\end{array}$ & $\begin{array}{l}\text { Exp } \\
=37\end{array}$ & $\begin{array}{l}67.95 \\
(8.75)\end{array}$ & $\begin{array}{l}24.29 \\
(2.33)\end{array}$ & NR & $\begin{array}{l}\leq 1: \\
8(21 \\
6 \%) \\
2-3: \\
21(56 \\
.8 \%) ;\end{array}$ & $\begin{array}{l}\text { Pre } \\
\text { mp: } \\
3(8.1 \\
\%) ; \\
\text { Peri } \\
\text { mp: }\end{array}$ & nil & nil & NR \\
\hline
\end{tabular}

POP surg or

hyst

POP surg 14

POP surg $9 \quad$ NR

This article is protected by copyright. All rights reserved. 


\begin{tabular}{|c|c|c|c|c|c|c|c|c|c|c|}
\hline & & & & & & $\begin{array}{l}\geq 4: \\
8(21 . \\
6 \%)\end{array}$ & $\begin{array}{l}2(5.4 \\
\%) ; \\
\text { Post } \\
\text { mp: } \\
32(86 . \\
5 \%) ; \\
\text { on } \\
\text { HRT: } \\
\text { 6(16.2 } \\
\%)\end{array}$ & & & \\
\hline & & $\begin{array}{l}\text { Con } \\
=30\end{array}$ & $\begin{array}{l}67.37 \\
(5.56)\end{array}$ & $\begin{array}{l}23.94 \\
(3.06)\end{array}$ & NR & $\begin{array}{l}\leq 1: \\
7(23 . \\
3 \%) ; \\
2-3: \\
14(46 \\
.7 \%) ; \\
\geq 4: \\
9(30 . \\
0 \%)\end{array}$ & $\begin{array}{l}\text { Pre } \\
\text { mp: } \\
3(10.0 \\
\%) ; \\
\text { Peri } \\
\text { mp: } \\
3(10.0 \\
\%) ; \\
\text { Post } \\
\text { mp: } \\
24(80 . \\
0 \%) ; \\
\text { on } \\
\text { HRT: } \\
7(23.3 \\
\text { \%) }\end{array}$ & nil & nil & \\
\hline $\begin{array}{l}\text { Yamana } \\
\text { et al., } \\
2006 \\
\text { (Japan) }\end{array}$ & $\begin{array}{l}\text { Prospect } \\
\text { ive } \\
\text { Cohort } \\
\text { Study }\end{array}$ & 30 & $\begin{array}{l}62[45- \\
78]\end{array}$ & NR & NR & $\begin{array}{l}\text { Nil - } \\
1(3 \% \\
), 1- \\
2(7 \% \\
), \geq 2 \\
-27 \\
(90 \% \\
)\end{array}$ & NR & $\begin{array}{l}\text { Rectocele } \\
\text { repair } \\
5(17 \%) ; \\
\text { haemorrhoid } \\
\text { ectomy } \\
\text { 10(33\%); } \\
\text { other anal } \\
\text { operations } \\
3(10 \%) ; \\
\text { hyst } 1(3 \%)\end{array}$ & NR & NR \\
\hline
\end{tabular}

Con = control group; Exp = experimental group; HRT = hormone replacement therapy; hyst $=$ hysterectomy; $\mathrm{mp}=$ menopausal; $\mathrm{NR}=$ not reported; nullip = nulliparous; primip = primiparous; $\mathrm{RCT}=$ randomised controlled trial; surg = surgery; $\mathrm{TAH}=$ Total Abdominal Hysterectomy; urogynae = urogynaecological

This article is protected by copyright. All rights reserved. 
TABLE 2. Interventions and outcome measures

\begin{tabular}{|c|c|c|c|c|c|c|}
\hline $\begin{array}{l}\text { Study } \\
\text { (Country) }\end{array}$ & Design & $\mathbf{n}$ & Diagnosis & $\begin{array}{l}\text { Intervention(s } \\
\text { ), (n) } \%\end{array}$ & $\begin{array}{l}\text { Outcome } \\
\text { measure(s) }\end{array}$ & $\begin{array}{l}\text { Follo } \\
\text { w-up } \\
\text { time }\end{array}$ \\
\hline $\begin{array}{l}\text { Andrew et al., } \\
2013 \\
\text { (Australia) }\end{array}$ & $\begin{array}{l}\text { Retrospectiv } \\
\text { e Cohort } \\
\text { Study }\end{array}$ & 81 & $\begin{array}{l}\text { POP 89\%; } \\
\text { SUI 74\%; } \\
\text { UUI 79\%; } \\
\text { Frequency } \\
\text { 48(59\%); } \\
\text { Nocturia } \\
52(64 \%) ; \text { VD } \\
35(43 \%)\end{array}$ & $\begin{array}{l}\text { Monarc 46(56.8\%); } \\
\text { TVT 1(1.2\%); } \\
\text { Anterior vaginal } \\
\text { repair 11(13.6\%); } \\
\text { Anterior vaginal } \\
\text { repair with mesh } \\
\text { 40(49.4\%); } \\
\text { Sacrospinous } \\
\text { colpopexy } \\
\text { 24(29.6\%); Vaginal } \\
\text { hysterectomy } \\
\text { 8(9.9\%); Posterior } \\
\text { vaginal repair } \\
\text { 41(50.6\%); posterior } \\
\text { vaginal repair with } \\
\text { mesh 8(9.9\%) }\end{array}$ & $\begin{array}{l}\text { Levator hiatal area } \\
\text { at rest \& PFMC } \\
\left(\mathrm{cm}^{2}\right) \text { on 3D } \\
\text { translabial U/S; } \\
\text { POP-Q }\end{array}$ & $\begin{array}{l}3-12 \\
\text { month } \\
\text { s }\end{array}$ \\
\hline $\begin{array}{l}\text { Barber et al., } \\
2014 \text { (USA) }\end{array}$ & $\begin{array}{l}\text { RCT Exp = } \\
\text { Surg } \\
+ \text { PFMT Con } \\
=\text { Surg + } \\
\text { usual care }\end{array}$ & $\begin{array}{l}\text { Exp = } \\
186 \\
\text { Con }= \\
188\end{array}$ & $\begin{array}{l}\text { Uterine } \\
\text { prolapse \& } \\
\text { SUI }\end{array}$ & $\begin{array}{l}\text { Uterosacral } \\
\text { ligament fixation } \\
\text { (ULS) or } \\
\text { sacrospinous } \\
\text { ligament fixation } \\
\text { (SSLF) and TVT + } \\
\text { PFMT }\end{array}$ & $\begin{array}{l}\text { Brink grading } \\
\text { system (3-12); } \\
\text { POP-Q }\end{array}$ & $\begin{array}{l}6,12 \\
\text { and } 24 \\
\text { month } \\
\text { s }\end{array}$ \\
\hline $\begin{array}{l}\text { Beilecke et al., } \\
2014 \\
\text { (Germany) }\end{array}$ & $\begin{array}{l}\text { Prospective } \\
\text { Cohort } \\
\text { Study }\end{array}$ & $\begin{array}{l}\text { Gp } 1 \\
=33 \\
\text { Gp } 2 \\
=37\end{array}$ & SUI & $\begin{array}{l}\text { Retropubic } \\
\text { suburethral sling } \\
\text { Transobturator } \\
\text { suburethral sling }\end{array}$ & $\begin{array}{l}\text { MOGS (0-5) in } \\
\text { supine and } \\
\text { standing; PFM } \\
\text { speed (0-10 } \\
\text { contractions in } \\
10 \text { s); PFM } \\
\text { endurance } \\
\text { (holding the } \\
\text { contraction up to } \\
10 \text { s) }\end{array}$ & $\begin{array}{l}6 \\
\text { weeks }\end{array}$ \\
\hline $\begin{array}{l}\text { Boccasanta et } \\
\text { al., } 2002 \text { (Italy) }\end{array}$ & $\begin{array}{l}\text { Prospective } \\
\text { Cohort } \\
\text { Study }\end{array}$ & 30 & $\begin{array}{l}\text { Anterior } \\
\text { rectocele } \\
100 \% \text {; FI } \\
13.3 \% \text {; SUI } \\
6.6 \%\end{array}$ & $\begin{array}{l}\text { Transrectal repair } \\
16(47.1 \%) ; \\
\text { Transrectal repair \& } \\
\text { perineal } \\
\text { levatorplasty } \\
14(46.7 \%)\end{array}$ & $\begin{array}{l}\text { Anal maximum } \\
\text { squeeze pressure } \\
\text { manometry } \\
(\mathrm{mmHg})\end{array}$ & $\begin{array}{l}3 \\
\text { month } \\
\text { s }\end{array}$ \\
\hline $\begin{array}{l}\text { Chen et al., } \\
2014 \text { (China) }\end{array}$ & $\begin{array}{l}\text { Prospective } \\
\text { Cohort } \\
\text { Study }\end{array}$ & $\begin{array}{l}\operatorname{Exp}= \\
74 \\
\text { Con }= \\
30\end{array}$ & $\begin{array}{l}\text { POP (stage II- } \\
\text { IV) }\end{array}$ & $\begin{array}{l}\text { Modified pelvic } \\
\text { reconstructive } \\
\text { surgery with mesh }\end{array}$ & $\begin{array}{l}\text { sEMG in crook } \\
\text { lying - MVC } \\
(\mu V) \text {; MVC } \\
\text { duration (s); no } \\
\text { SFC; SFC }(\mu \mathrm{V}) \text {; } \\
\text { MOGS }(0-5) \text { in } \\
\text { bent-knee lying; } \\
\text { POP-Q }\end{array}$ & $\begin{array}{l}3 \\
\text { month } \\
\text { s }\end{array}$ \\
\hline $\begin{array}{l}\text { Dekel et al., } \\
2000 \text { (Israel) }\end{array}$ & $\begin{array}{l}\text { Prospective } \\
\text { Cohort } \\
\text { Study }\end{array}$ & 10 & $\begin{array}{l}\text { Uterine } \\
\text { prolapse, } \\
\text { cystorectocele } \\
\text { and rectal }\end{array}$ & $\begin{array}{l}\text { Vaginal } \\
\text { hysterectomy with } \\
\text { anterior \& posterior } \\
\text { colporrhaphies \& }\end{array}$ & $\begin{array}{l}\text { Anal maximum } \\
\text { squeeze pressure } \\
\text { manometry } \\
(\mathrm{mmHg})\end{array}$ & $\begin{array}{l}6 \\
\text { month } \\
\text { s }\end{array}$ \\
\hline
\end{tabular}

This article is protected by copyright. All rights reserved. 


\begin{tabular}{|c|c|c|c|c|c|c|}
\hline & & & prolapse & $\begin{array}{l}\text { transperineal } \\
\text { rectosigmoidectomy }\end{array}$ & & \\
\hline $\begin{array}{l}\text { Digesu et al., } \\
2014 \text { (Italy) }\end{array}$ & $\begin{array}{l}\text { Prospective } \\
\text { Cohort } \\
\text { Study }\end{array}$ & 28 & SUI & $\begin{array}{l}\text { Burch } \\
\text { colposuspension }\end{array}$ & $\begin{array}{l}\text { Distance }(\mathrm{cm}) \\
\text { levator ani to } \\
\text { pubococcygeal } \\
\text { line; bladder neck } \\
\text { to levator ani; } \\
\text { bladder neck to } \\
\text { pubococcygeal } \\
\text { line on MRI }\end{array}$ & 1 year \\
\hline $\begin{array}{l}\text { Duarte et al., } \\
2018 \text { (Brazil) }\end{array}$ & $\begin{array}{l}\text { Prospective } \\
\text { Cohort }\end{array}$ & 67 & $\begin{array}{l}\text { POP (stage II- } \\
\text { IV) }\end{array}$ & $\begin{array}{l}\text { Anterior } \\
\text { colpoperineoplasty } \\
(61 \%) \text {; anterior \& } \\
\text { posterior } \\
\text { colpoperineoplasty } \\
(26.6 \%) \text {; posterior } \\
\text { colpoperineoplasty } \\
(7.6 \%) \text {, } \\
\text { hysterectomy } \\
(4.6 \%)\end{array}$ & $\begin{array}{l}\text { MOGS (0-5) bent- } \\
\text { knee lying; } \\
\text { vaginal squeeze } \\
\text { pressure } \\
\text { manometry (peak } \\
\text { of MVC, duration } \\
\text { of MVC and } \\
\text { average - cm } \mathrm{H}_{2} \mathrm{O} \text {, } \\
\text { sec) bent-knee } \\
\text { lying, POP-Q }\end{array}$ & $\begin{array}{l}40 \\
\text { days }\end{array}$ \\
\hline $\begin{array}{l}\text { Frawley et al., } \\
2010 \\
\text { (Australia) }\end{array}$ & $\begin{array}{l}\text { RCT Exp = } \\
\text { Surg }+ \\
\text { PFMT Con } \\
=\text { Surg }+ \\
\text { usual care }\end{array}$ & $\begin{array}{l}\operatorname{Exp}= \\
27 \\
\text { Con }= \\
24\end{array}$ & $\begin{array}{l}\text { UI 51\%, POP } \\
92 \%\end{array}$ & $\begin{array}{l}\text { POP vaginal repair } \\
\text { (16) 31.4\%; Vaginal } \\
\text { hysterectomy (6) } \\
11.8 \% \text {; POP repair } \\
\text { \& hysterectomy (27) } \\
52.9 \% \text {; }\end{array}$ & $\begin{array}{l}\text { MOGS }(0-5) \text {; } \\
\text { vaginal squeeze } \\
\text { pressure } \\
\text { manometry peak } \\
\text { max, VSP area } \\
\max \left(\mathrm{cm} \mathrm{H}_{2} \mathrm{O}\right) \\
\end{array}$ & $\begin{array}{l}3,6 \\
\text { and } 12 \\
\text { month } \\
\mathrm{s}\end{array}$ \\
\hline $\begin{array}{l}\text { Guan et al., } \\
2015 \text { (China) }\end{array}$ & $\begin{array}{l}\text { Prospective } \\
\text { Cohort }\end{array}$ & $\begin{array}{l}\text { Exp = } \\
37 \\
\text { Con } \\
=30\end{array}$ & $\begin{array}{l}\text { POP (stage III } \\
\text { or IV) }\end{array}$ & $\begin{array}{l}\text { Total pelvic floor } \\
\text { reconstruction (20) } \\
54.1 \% \text {; anterior wall } \\
\text { reconstruction (10) } \\
27.0 \% \text {; posterior } \\
\text { wall reconstruction } \\
\text { (7) } 18.9 \% \\
\end{array}$ & MOGS (0-5) & $\begin{array}{l}3 \\
\text { month } \\
\mathrm{s}\end{array}$ \\
\hline $\begin{array}{l}\text { Hanzal et al., } \\
1993 \text { (Austria) }\end{array}$ & $\begin{array}{l}\text { Prospective } \\
\text { Cohort }\end{array}$ & 30 & POP \& SUI & $\begin{array}{l}\text { Vaginal } \\
\text { hysterectomy \& } \\
\text { anteroposterior } \\
\text { repair }\end{array}$ & $\begin{array}{l}\text { Perineal } \\
\text { sonography - } \\
\text { Retrovesical angle } \\
\text { at rest }\left(^{\circ}\right) \text {; distance } \\
\text { between } \\
\text { transducer head; } \\
\text { and urethrovesical } \\
\text { junction at rest } \\
(\mathrm{cm})\end{array}$ & $\begin{array}{l}41 \\
\text { month } \\
\text { s [37- } \\
44 \\
\text { month } \\
\text { s] }\end{array}$ \\
\hline $\begin{array}{l}\text { Huang et al., } \\
2017 \text { (Taiwan) }\end{array}$ & $\begin{array}{l}\text { Retrospectiv } \\
\text { e Cohort } \\
\text { Study }\end{array}$ & 145 & $\begin{array}{l}\text { Cystocele } \\
\text { (stage III or } \\
\text { IV) }\end{array}$ & Perigree procedure & $\begin{array}{l}\text { Bladder neck } \\
\text { distance }(\mathrm{cm}) \text {; } \\
\text { bladder neck angle } \\
\left(^{\circ}\right) \text {; genitohiatal } \\
\text { distance }(\mathrm{cm}) \text {; } \\
\text { genitohiatal angle } \\
\left(^{\circ}\right) \text { at rest; on } \\
\text { PFMC; on } \\
\text { coughing using } \\
\text { 4D introital } \\
\text { ultrasound; POP- } \\
\text { Q }\end{array}$ & $\begin{array}{l}12 \\
\text { month } \\
\mathrm{s}\end{array}$ \\
\hline
\end{tabular}

This article is protected by copyright. All rights reserved. 


\begin{tabular}{|c|c|c|c|c|c|c|}
\hline $\begin{array}{l}\text { Jarvis et al., } \\
2005 \\
\text { (Australia) }\end{array}$ & $\begin{array}{l}\text { RCT Exp = } \\
\text { Surg + } \\
\text { PFMT Con } \\
=\text { Surg + } \\
\text { usual care }\end{array}$ & $\begin{array}{l}\operatorname{Exp}= \\
30 \\
\text { Con }= \\
30\end{array}$ & $\begin{array}{l}\text { UI } 26.7 \% \text {, } \\
\text { POP } 61.7 \%\end{array}$ & $\begin{array}{l}\text { POP \& urinary } \\
\text { incontinence } \\
\text { procedure (14) } \\
23.3 \% \text {; POP } \\
\text { procedure (23) } \\
\text { 38.3\%; Incontinence } \\
\text { procedure (2) 3.3\%; }\end{array}$ & $\begin{array}{l}\text { Vaginal squeeze } \\
\text { pressure } \\
\text { manometry (cm } \\
\mathrm{H}_{2} \mathrm{O} \text { ) }\end{array}$ & $\begin{array}{l}3 \\
\text { month } \\
\text { s }\end{array}$ \\
\hline $\begin{array}{l}\text { Liang et al., } \\
2015 \text { (China) }\end{array}$ & $\begin{array}{l}\text { Prospective } \\
\text { Cohort } \\
\text { Study Gp } 1 \\
=\text { mesh Gp } 2 \\
=\text { no mesh }\end{array}$ & $\begin{array}{l}\text { Gp } 1 \\
=7 \\
\text { Gp } 2 \\
=10\end{array}$ & $\begin{array}{l}\text { POP (grade } \\
\text { III-IV)1 }\end{array}$ & $\begin{array}{l}\text { Pelvic floor } \\
\text { reconstruction with } \\
\text { Prosima (5) 22.7\%; } \\
\text { Pelvic floor } \\
\text { reconstruction with } \\
\text { Prolift (2) 9.1\%; } \\
\text { Modified pelvic } \\
\text { floor reconstructive } \\
\text { surgery (8) 36.4\%; } \\
\text { Sacrospinous } \\
\text { ligament fixation (2) } \\
\text { 9.1\%; All had } \\
\text { concomitant vaginal } \\
\text { hysterectomy (17) } \\
77.3 \%\end{array}$ & $\begin{array}{l}\text { Anal maximum } \\
\text { squeeze pressure } \\
\text { manometry } \\
\text { (mmHg); POP-Q }\end{array}$ & $\begin{array}{l}3 \\
\text { month } \\
\text { s }\end{array}$ \\
\hline \multirow[t]{2}{*}{$\begin{array}{l}\text { Lone et al., } \\
2013 \text { (United } \\
\text { Kingdom) }\end{array}$} & $\begin{array}{l}\text { Prospective } \\
\text { Cohort } \\
\text { Study } \\
\text { Gp1 = } \\
\text { Surgery; } \\
\text { Gp } 2 \text { = } \\
\text { Pessary; }\end{array}$ & $\begin{array}{l}\text { Gp } 1 \\
=43 \\
\text { Gp } 2 \\
=10 \\
\text { Gp } 3 \\
=34\end{array}$ & POP & $\begin{array}{l}\text { Anterior repair (32) } \\
74.4 \% \text {; Posterior } \\
\text { repair (10) 23.3\%; } \\
\text { Vaginal } \\
\text { hysterectomy (16) } \\
37.2 \% \text {; } \\
\text { Sacrospinous } \\
\text { fixation (2) 4.7\%; } \\
\text { Sacrocolpopexy (2) } \\
4.7 \%\end{array}$ & $\begin{array}{l}\text { Endovaginal } \\
\text { ultrasound - LH } \\
\text { area (cm2); LA } \\
\text { AP (mm); LH L-R } \\
\text { (mm); POP-Q }\end{array}$ & 1 year \\
\hline & $\begin{array}{l}\text { Gp } 3=\text { no } \\
\text { treatment }\end{array}$ & & & & & \\
\hline $\begin{array}{l}\text { McClurg et al., } \\
2014 \text { (United } \\
\text { Kingdom) }\end{array}$ & $\begin{array}{l}\text { RCT Exp = } \\
\text { Surg + } \\
\text { PFMT Con } \\
=\text { Surg }+ \\
\text { usual care }\end{array}$ & $\begin{array}{l}\operatorname{Exp}= \\
28 \\
\text { Con }= \\
29\end{array}$ & $\begin{array}{l}\text { POP (anterior } \\
\text { POP 50\%) }\end{array}$ & POP surgery & $\begin{array}{l}\text { MOGS (0-5) } \\
\text { modified dorsal } \\
\text { lithotomy } \\
\text { position; POP-Q }\end{array}$ & $\begin{array}{l}0,6 \\
\text { and } 12 \\
\text { month } \\
\text { s }\end{array}$ \\
\hline $\begin{array}{l}\text { Mouritsen et } \\
\text { al., } 2007 \\
\text { (Denmark) }\end{array}$ & $\begin{array}{l}\text { Prospective } \\
\text { Cohort } \\
\text { Study }\end{array}$ & 23 & $\begin{array}{l}\text { POP (stage II- } \\
\text { III) }\end{array}$ & Vaginal repair & $\begin{array}{l}\text { Vaginal squeeze } \\
\text { pressure } \\
\text { manometry (cm } \\
\mathrm{H}_{2} \mathrm{O} \text { ) in sitting; } \\
\text { POP-Q }\end{array}$ & $\begin{array}{l}1-5 \\
\text { days } \\
\text { and 4- } \\
6 \\
\text { weeks }\end{array}$ \\
\hline $\begin{array}{l}\text { Pauls et al., } \\
2014 \text { (USA) }\end{array}$ & $\begin{array}{l}\text { RCT Exp = } \\
\text { Surg + } \\
\text { PFMT Con } \\
=\text { Surg + } \\
\text { usual care }\end{array}$ & $\begin{array}{l}\operatorname{Exp}= \\
29 \\
\text { Con }= \\
28\end{array}$ & $\begin{array}{l}\text { POP and / or } \\
\text { UI }\end{array}$ & $\begin{array}{l}\text { Total vaginal } \\
\text { hysterectomy } \\
\text { 43(75.4\%); Anterior } \\
\text { repair 46(80.7\%); } \\
\text { Posterior repair } \\
\text { 46(80.7\%); } \\
\text { Enterocele repair } \\
\text { 40(70.2\%); Vaginal } \\
\text { vault suspension } \\
\text { 42(73.7\%); TVT } \\
\text { 2(3.5\%); TVT-O } \\
\text { 10(17.5\%) }\end{array}$ & $\begin{array}{l}\text { MOGS supine (0- } \\
\text { 5); intravaginal } \\
\text { EMG - rapid } \\
\text { contractions } \\
\text { average of peaks; } \\
\text { work-rest phase } \\
\text { work average; } \\
\text { endurance phase } \\
\text { work average } \\
(\mu V) ; \text { POP-Q } \\
\text { supine }\end{array}$ & $\begin{array}{l}12 \text { and } \\
24 \\
\text { weeks }\end{array}$ \\
\hline
\end{tabular}

This article is protected by copyright. All rights reserved. 


\begin{tabular}{|c|c|c|c|c|c|c|}
\hline $\begin{array}{l}\text { Rinne et al., } \\
2011 \text { (Finland) }\end{array}$ & $\begin{array}{l}\text { Prospective } \\
\text { Cohort } \\
\text { Study }\end{array}$ & $\begin{array}{l}\operatorname{Exp}= \\
42 \\
\text { Con }= \\
16\end{array}$ & SUI & $\begin{array}{l}\text { TVT 21(50\%); } \\
\text { TVT-O 21(50\%) }\end{array}$ & $\begin{array}{l}\text { Position of mid- } \\
\text { urethra (at rest, on } \\
\text { PFMC) on MRI in } \\
\text { bent-knee lying }\end{array}$ & $\begin{array}{l}3-6 \\
\text { month } \\
\text { s }\end{array}$ \\
\hline $\begin{array}{l}\text { Wang et al., } \\
2013 \text { (China) }\end{array}$ & $\begin{array}{l}\text { Prospective } \\
\text { Cohort } \\
\text { Study }\end{array}$ & $\begin{array}{l}\operatorname{Exp}= \\
37 \\
\text { Con }= \\
30\end{array}$ & $\begin{array}{l}\text { POP (stage II- } \\
\text { IV) no POP, } \\
\text { other gynae } \\
\text { issues }\end{array}$ & Prolift repair & $\begin{array}{l}\text { sEMG crook lying } \\
\text { - MVC } \\
(\mu V) ; M V C \\
\text { duration }(s) ; \text { no } \\
\text { SFC; SFC }(\mu V) ; \\
\text { POP-Q }\end{array}$ & $\begin{array}{l}3 \\
\text { month } \\
\text { s }\end{array}$ \\
\hline $\begin{array}{l}\text { Yamana et al., } \\
2006 \text { (Japan) }\end{array}$ & $\begin{array}{l}\text { Prospective } \\
\text { Cohort } \\
\text { Study }\end{array}$ & 30 & $\begin{array}{l}\text { Rectocele } \\
\text { (large, } \\
\text { symptomatic) }\end{array}$ & $\begin{array}{l}\text { Anterior } \\
\text { levatorplasty }\end{array}$ & $\begin{array}{l}\text { Anal maximum } \\
\text { squeeze pressure } \\
\text { manometry } \\
(\mathrm{mmHg})\end{array}$ & $\begin{array}{l}6 \\
\text { month } \\
\text { s }\end{array}$ \\
\hline
\end{tabular}

Con = control group; Exp = experimental group; FI = faecal incontinence; gynae = gynaecological; hyst = hysterectomy; MOGS = modified oxford grading scale; $\mathrm{MVC}=$ maximum voluntary contraction; no = number; $\mathrm{NR}=$ not reported; $\mathrm{PFMC}=$ pelvic floor muscle contraction; PFMT = pelvic floor muscle training; POP = pelvic organ prolapse; POP-Q = pelvic organ prolapse quantification system; RCT = randomized controlled trial; SUI = stress urinary incontinence; sEMG = surface electromyography; SFC = short fast contractions; surg = surgery; TAH = Total Abdominal Hysterectomy; TVT = tension-free vaginal tape; TVT-O = tension-free obturator tape; urogynae = urogynaecological; U/S: ultrasound; UUI = urge urinary incontinence; VD = voiding dysfunction 


\section{University Library}

\section{- M I N E R VA \\ A gateway to Melbourne's research publications}

Minerva Access is the Institutional Repository of The University of Melbourne

Author/s:

Mastwyk, S;McClelland, J;Rosamilia, A;Frawley, H

Title:

The impact of pelvic organ prolapse and/or continence surgery on pelvic floor muscle function in women: A systematic review

Date:

2019-08-01

\section{Citation:}

Mastwyk, S., McClelland, J., Rosamilia, A. \& Frawley, H. (2019). The impact of pelvic organ prolapse and/or continence surgery on pelvic floor muscle function in women: $A$ systematic review. NEUROUROLOGY AND URODYNAMICS, 38 (6), pp.1467-1481. https:// doi.org/10.1002/nau.24025.

Persistent Link:

http://hdl.handle.net/11343/285889 